\title{
Socio-Cultural Dispositions and Wellbeing of the Women Left Behind: A Case of Migrant Households in Nepal
}

\author{
Hom Nath Gartaula $\cdot$ Leontine Visser • Anke Niehof
}

Accepted: 30 May 2011/Published online: 11 June 2011

(C) The Author(s) 2011. This article is published with open access at Springerlink.com

\begin{abstract}
The concept of wellbeing is gaining popularity in the study of quality of life and cultural significance of living. The paper aims to contribute to our understanding of objective and subjective wellbeing by exploring the perceptions of women left behind by out-migrating husbands on their quality of life in a transnational social field. The paper uses both qualitative and quantitative research methods. Its primary focus is on the life stories of the four women left behind by their migrant husbands, complementing by quantitative data obtained from a survey among 277 households. Taking an example from Nepal's eastern terai, the paper shows that additional income from remittances has increased the objective wellbeing of the women left behind, but it may not have increased their subjective wellbeing. Hence, it is concluded that improved objective wellbeing of a woman does not necessarily translate into her (improved) subjective wellbeing. The subjective experiences are rather complex, multi-faceted and context specific depending on the family situation, socio-cultural disposition and prior economic situation of the actors involved.
\end{abstract}

Keywords Objective wellbeing - Subjective wellbeing - Male out-migration · Women left behind · Rural Nepal

\section{Introduction}

Movement of people from Nepal to India and other countries shows a history of about 200 years, encompassing pilgrims, devotees, political refugees, and soldiers. During the

H. N. Gartaula (两) - L. Visser · A. Niehof

Department of Social Sciences, Wageningen University, Wageningen, The Netherlands e-mail: hom.gartaula@gmail.com

L. Visser

e-mail: leontine.visser@wur.nl

A. Niehof

e-mail: anke.niehof@wur.nl 
last quarter of the twentieth century, Nepal has increasingly become a labour exporting country (Kollmair et al. 2006; Seddon et al. 2002; Thieme and Wyss 2005). Government statistics show that about three per cent of the Nepalese live abroad (CBS 2001); many of them are labour migrants. Out-migration in Nepal is mostly transnational: 77 per cent migrate to India and 15 per cent to the Gulf countries (CBS 2001). Male out-migration has not only contributed to the national economy, but it has also affected the people remaining back home. For example, one-fifth of the poverty reduction occurring between 1995 and 2004 is claimed to be due to labour out-migration (Lokshin et al. 2007). While almost half of the world's migrant population is female (Ramirez et al. 2005), in Nepal 90 per cent is male (CBS 2004).

The revolution of information and communication technology coupled with increased labour demand in the developed countries has meant that many people are able to live transnationally "maintaining significant social, economic and cultural ties with countries of origin and with fellow migrants elsewhere" (Grillo and Mazzucato 2008: 176). Hence, the study of migration is no longer restricted to the conventional 'pull and push' factors causing migration as specified by Harris and Todaro model (cited in Taylor 1999). It rather demands an integrated study of the social, cultural, political, and economic dimensions of the migration experience (Kaur 2006; Sharma 2008). This paper highlights the sociocultural dispositions of women left behind by transnational migrants. While their husbands earn a living by working abroad, especially in the Gulf countries and Malaysia, their wives are engaged in running the family and the household back home.

The migration literature often focus on either the conditions in the areas of destination or on the migrants themselves and their economic contributions to their home country, disregarding the socio-cultural dimensions of their moving out that are equally important in migration research (Sharma 2008). Moreover, the people left behind are often invisible, and their role, experience, wellbeing and interconnectedness with the practice of migration are not well understood (Hadi 1999; Nguyen et al. 2006). However, scholars have recently started to explore the dynamics of the people left behind within the framework of 'migration-left-behind nexus' (Jones and Kittisuksathit 2003; Rigg 2007; Toyota et al. 2007; Xiang 2007). It is also deemed important to focus not just on the transnational processes at the level of organisations, enterprises and communities, but also on the social practices of transnationalism as they affect the family or the household across the two spaces of origin and destination (Grillo and Mazzucato 2008; Yeoh et al. 2005).

This paper contributes to these recent studies by exploring how the migration of their husbands has provided an objective wellbeing to the migrants' wives and how they experience and subjectively perceive their quality of life. There appears to be a marked difference related to their social position in two different household arrangements: those women living as de-facto female heads of households and those living with in-laws. Taking an example from Nepal's eastern terai and its transnational networks, the paper contributes to our understanding of wellbeing by exploring people's transnational experiences within the realm of a family or a household.

\section{Left-Behind Women in the Transnational Social Field}

Even though transnational mobility is not a new phenomenon, it has not acquired sufficient attention as an emergent social field. The field comprises persons who are double engaged in living simultaneously in a continuous space: speaking two languages, having homes in two countries, and making a living through regular contact across national borders (Grillo 
and Mazzucato 2008; Portes et al. 1999). Portes et al. (1999: 217) define transnationalism as the activities pertaining "to the creation of a transnational community linking immigrant groups [migrant workers] in the advanced countries with their respective sending nations and hometowns". The transnational network is composed of "migrants and the people they transact with, who are located in various countries, be they friends, family, colleagues or others" (Mazzucato 2008: 201). Most literature focuses on the migrants, but it is as important to include the experiences of those left behind, particularly the women because migration is not an individual decision, but it involves the whole family, albeit in different ways (de Haas 2005; Velayutham and Wise 2005; Yeoh et al. 2005). Moreover, migration is a cultural matter, as it forms part and parcel of people's lives aiming to improve their wellbeing (Gartaula 2009; Rigg 2007).

The impact of migration on the source communities and those left behind is an evolving process rather than something which can be regarded as predictable and fixed (Rigg 2007). Xiang (2007) reports that being physically left-behind by migrants; the rural communities in China have also been left behind economically and socially. He shows not only the relationship between the two places of origin and destination, but also the (lack of) wellbeing of the people left behind. Hadi (1999) reports how labour migrants interact with their family members back home in many ways that help modify the traditional behaviour and values of the people left behind which also influence their wellbeing. Therefore, before we describe the Nepalese cases, we need to explain the family context by clarifying the local meanings of 'marriage' and 'household', and their significance for the 'wellbeing' of the actors involved.

The institution of marriage is the origin of a family that also entails household formation, and it symbolises a significant social transition in the life course of both men and women. In Nepal, monogamy and virilocal residency prevail. The newly married bride abodes for the rest of her life in her husband's house. The newly married couple forms a family, and generates a means of living and produces and rears children. In most cases they live with the parents or other members of husband's family, but in some cases the couple forms a nuclear family in a new home and earn a livelihood independently. In both situations, they realise that, as responsible persons, they should not continuously rely on their parents (or in-laws) for a living. In a context of virilocal residence, however, the social position and wellbeing of a married woman greatly differs from that of a man. The system compels the wife and daughter-in-law to live in a new place with strange people, as the marriages are traditionally arranged by the parents leaving little or no opportunity for bride and groom to get to know each other before marriage.

A household is "a co-residential unit, usually family-based in some way, which takes care of resource management and primary needs of its members" (Rudie 1995: 228). Rudie also mentions that such a support unit may include non-resident members, which is a relevant notion in migration research. However, we prefer to speak of support relations as a part of a transnational support network of the household, which broadens the concept of household to a collective of both resident and non-resident members who strive for the wellbeing of its members by mobilising resources and fulfilling primary needs, both "here" and "there". This notion of a transnational network is in line with, Elmhirst (2008) who conceptualises the multi-locality of (household) livelihoods corresponding to the notion of support relations among resident and non-resident members. Taking the de Haan and Zoomers' (2005) idea of 'livelihood trajectories' and Krishna's (2004) 'genderscape' respectively, she discusses the household and its networks traversing the temporal, social and geographical spaces for resource management and needs fulfilment (Elmhirst 2008: 69). 
The distribution of wellbeing inside the household depends on the preferences, interests and decision-making power of the household members involved. Agarwal (1997: 3) describes the household as an arena of interaction and negotiation among its members. Sen (1990) sees household as a site of both cooperation (adding to total availabilities) and conflict (dividing the total availabilities among household members). The social position of a member depends on bargaining power as the outside option that determines how well-off a person would be if cooperation within the household failed (Agarwal 1997). Niehof (forthcoming) argues that the household structures people's daily life to provide for their needs and wellbeing, and assuming responsibility for dependents and family members. Hence, a household can be seen as the arena of day-to-day life of its members, regardless of their spatial place of residence at any particular moment, for generating and mobilising resources and fulfilling the primary needs and wellbeing.

Recently, the concept of wellbeing has gained significance in social anthropology and development studies by incorporating people's perception of the quality of life and cultural significance of resources in livelihood generation (Brons et al. 2007; McGregor 2004; Ontita 2007; White and Ellison 2006). The study of wellbeing has two strands: objective wellbeing, normatively based on the universality of basic human needs required for a good life (Doyal and Gough 1991) and subjective wellbeing, based on people's socially and culturally underpinned perception of their quality of life (cf. Royo and Velazco 2006). Newton (2007: 4) incorporated both objective and subjective wellbeing to understand people's life in a holistic way: "Wellbeing is conceived as arising from a person's material/ objective, cognitive/subjective and relational conditions". McGregor (2004: 345) notes, "at any point in time the wellbeing of an individual is the outcome of the resources they have; the needs that they are able to fulfil; and their subjective evaluation of their state of wellbeing. These three outcomes are interconnected and are reproduced in the process of interaction with wider structures of family, community and society."

Inspired by the Theory of Human Need (Doyal and Gough 1991), the paper considers availability and access to food and water, education, housing, employment, and care as need satisfiers for objective wellbeing. The subjective wellbeing, on the other hand, is based on self-reported experiences of migrants' wives on their life satisfaction and primary relationships with in-laws and husbands. This is because wellbeing of migrants' wives may differ according to their social position and residence, since social and cultural contexts influence the way people understand and experience happiness and wellbeing (Camfield et al. 2007). In Nepal, for example, women as heads-of-household would perceive wellbeing differently from women living with in-laws. The latter have less autonomy, social status, and self-esteem, but, on the other hand, women living with in-laws have other family members to share the burden of her husband being away. In this context, the present research can contribute to our understanding of wellbeing by looking at how Nepalese migrants' wives perceive their wellbeing, and how their wellbeing differs according to the type of household they live in.

\section{The Research}

The paper is based on a fieldwork carried out in Maharanijhoda Village Development Committee (VDC) of Jhapa district in eastern Nepal in 2008-2009. Maharanijhoda is one of the 47 VDCs and three municipalities in Jhapa district. Having a population of 10,589 living in 1980 households (DDC 2006), Maharanijhoda is located at $56 \mathrm{~km}$ west of the district headquarters, Chandragadhi, and $550 \mathrm{~km}$ east of the country's capital of 
Kathmandu. In the research area, the majority of the population belongs to the high caste Brahmin-Chhetri (64.2\%) and Janajati (17.3\%) groups both of whom once migrated from the north-eastern hills of the country and dominate the current wave of labour outmigration.

Including data obtained from a survey among 277 households, this paper focuses on the qualitative data from the subjective experience of wives of migrant workers who are either de-facto heads-of-households or who are staying with their parents-in-law. The paper particularly draws upon the experience of four women, whose husbands were working abroad during the time of fieldwork. We have selected two women who are living with inlaws and two others who are acting as de-facto heads of the household. The cases are constructed based on several observational visits and in-depth interviews in their homestead. The first author selected and instructed a female interviewer from outside the VDC to conduct the interviews. This was done to facilitate the interviews in more open atmosphere because: (1) as sensitive issues like the relationship with the husband and in-laws would have been difficult to discuss with a male interviewer, (2) since the interviewer was not from within their neighbourhood, the women would talk more openly to her than to a person from within the village who could be suspected to possible gossip about the information provided. The qualitative data are supplemented by the quantitative data from the survey.

All households in the research area are engaged in diverse economic activities. Nonfarm labour outside the village both within and outside Nepal is one of the main sources of cash income. The majority of labour migrants is male (87\%), married (82\%), young (average age 29), and unskilled (60\%), working in both formal and informal sectors at their destination. In 2008, more than 40 per cent of the sampled households received remittances from their migrant members.

\section{Results and Discussion}

The results are presented in the order of objective and subjective wellbeing. Following Doyal and Gough (1991) the objective measurement of wellbeing is presented with the help of quantitative data by taking into account of availability and access to food and water, education, housing, employment, healthcare, and childcare considering them as the basic need satisfiers. Subjective wellbeing is presented as the subjective experience of the four women left behind by migrant workers in different household arrangements.

\subsection{Objective Wellbeing}

The Maharanijhoda VDC of Jhapa appears to have relatively good infrastructure, accessibility, ICT facilities, and agricultural production, all necessary conditions for meeting people's objective or material needs. The income is important for objective wellbeing, as higher income increases the capacity to satisfy human needs. The literature suggests a positive relationship between income and life satisfaction (Schyns 2002). The average total household income of the VDC for the year 2008 was calculated as being NPR 176,000, ${ }^{1}$ while that of migrant households was NPR 277,000 and that of non-migrant households NPR 54,000. Remittances contributed 30 per cent of the total household income of the

1 The exchange rate at the time of fieldwork for EUR 1 was about NPR 100; NPR stands for Nepalese Rupees. 
sampled households. Other sources of income are trade and business $(28 \%)$, salary from formal sector employment (17\%), wage labour (10\%), cash income from agriculture (6\%), income from rent and other sources of income (9\%), which indicates the relative importance of labour out-migration and other non-agricultural sectors as need satisfiers. These findings are supported by the literature, which shows that migration is positively associated with economic indicators (Kuhn 2006; Massey et al. 1993; Taylor et al. 1996).

In terms of availability and access to food and water, 71.8 per cent of the households have land for both agriculture and residential purposes, while 22.7 per cent have only residential land and 5.4 per cent have no land at all. The average total landholding size is 0.80 ha per household, that of migrant households 0.83 ha and of non-migrant 0.77 ha per household. There are no canal irrigation facilities, over 50 per cent households own motor pumps for getting water from underground tube-wells. Over 92 per cent households have hand-pumps to extract drinking water from bore-holes installed at their homestead, of which 47 per cent are migrant households. Another eight per cent have to depend on public sources for drinking water. In none of the cases below any problems in accessing food and water were indicated. The women in Cases 1 and 2 are food secure regardless of their husband's migration, while in Cases 3 and 4 they had experienced problems with accessing food prior to migration. The remittances being sent by their husbands are used either to buy rice directly or to increase agricultural production through input support.

The presence of two government secondary schools, government primary schools in almost all nine wards of the VDC, and five private boarding schools within the VDC shows that the area's educational facilities are well accessible to school going children. In addition, adjoining VDCs have almost equal numbers of both government and private schools. Almost 80 per cent of the surveyed population were found literate. The cases presented illustrate that women send their children to private schools, which are considered to provide higher quality education than government schools. For example, Ushadevi (Case 4) moved her children from a government to a private school, for which she has to pay monthly fees whereas government schools do not charge fees. Kuhn (2006) observed a positive correlation between children's schooling and out-migration of male household members in rural Bangladesh.

In terms of housing as a need satisfier, over 98 per cent households have their own house. Eight out of ten of the concrete houses of the sampled households have corrugated iron sheets roofing and the remaining ones have slab roofing. The rest of the households have a traditional type of houses with wooden/bamboo walls and thatch or corrugated iron sheets roofing. This indicates a gradual replacement of wooden houses by modern concrete ones. Their increase in number can be partly attributed to the scarcity and high cost of wooden materials and partly to people's increased access to capital, primarily through remittances. Case 4 has replaced the house at the same place, Cases 1 and 3 have bought residential plots in town and Case 2 has an aspiration to build a house if she could make a surplus of the remittances. In general, the households in the research area have their own house for living, as an indicator of positive wellbeing.

Agriculture is considered a primary source of employment in the VDC. The majority of men and women work on their own land, while those who do not have land can work as agricultural labourers and also for them agriculture is their main occupation. However, people consider only non-agricultural work 'employment', which is a major reason for the current wave of young adults choosing foreign employment. While over 81 per cent of the households reported agriculture as a primary source of occupation, 49.6 per cent reported foreign employment as the second source of occupation. Half of the sample households 
have at least one migrant member. The combination of agriculture and other sources of income are contributing to fulfil the basic needs of household and the individuals.

Considering healthcare, there are no hospitals and childcare centres within the VDC but there are four hospitals at a distance of about 14 kilometres. There are a number of private clinics within the VDC and in adjoining VDCs, which also contribute to the supply of health services in the area. Availability of healthcare facilities, however, does not imply equal accessibility because the latter also depends on income. Our research indicates a higher capacity of migrant households in assuring health services, which is supported by studies in India and Bangladesh that show an association between migration and good health (cf. Hadi 1999; Nguyen et al. 2006).

The above shows that the additional income from remittances has helped enhancing objective wellbeing of the people in the research area and those remittances provide a safety-net for the women left behind. Moreover, as was also observed by Hoermann et al. (2010: 1) "the benefits of remittances are not limited to recipient households, but have a wider impact on the receiving society as remittances are spent, generating demand and jobs for local workers. Remittances improve living conditions, education, and health in the origin communities, and provide insurance against income shocks". However, the subjective account of wellbeing of the women left behind tells a different story, which is described in the next section.

\subsection{Subjective Wellbeing}

The cases presented below are compared along two axes: residence and income class. The women of Cases 1 and 3 were living with their in-laws, and they were from relatively wellto-do families. The women of Cases 2 and 4 were de-facto female heads of the household at the time of fieldwork, and they were less well off than in the women in Cases 1 and 3. Each case description starts with a general introduction of the women interviewed and their family, followed by the migration history and their involvement in the migration decisions, the use and strategies of using remittances, their experiences as being migrant's wives, their relationship especially with the parents-in-law, and finally communication and bonding in their relationship with the husbands. In all cases the marriage was based on a traditional marriage arrangement. Except for the introductions, the cases use the translated verbatim language of the respondents.

\subsubsection{Case 1: Suhana Dignita, Cannot Share the Feelings}

4.2.1.1 Introduction Suhana (25) was married with Pebi in 2002 at the age of 20. At that time, her husband was 27 years old. She has up to SLC (School Level Certificate) level education. Her husband has been working in Dubai for the last 2 years. Among her two brothers-in-law, one works in Qatar and another one works at another district for the Nepal Police. Her second brother-in-law (the one working in Qatar) is not yet married, but the last brother-in-law is married with Tama, living together with Suhana with their parents-in-law. Tama's husband frequently visits home as he is posted nearby, but other two brothers visit home at about a 2 years interval. The couple has one son, Susant (aged 4), enrolled at a private Kindergarten.

4.2.1.2 Migration: Decision and Involvement "I was aware of his move from the beginning, but I was not involved in the decision-making. He discussed it with his parents 
and told me that he was going out. Actually, I have no idea why he wanted to go out; he just informed me about his going. When he told me I liked the idea, as everybody was going out to make money abroad, so I did not think otherwise of his idea of going out though I was not feeling happy about it.

As my father-in-law is a businessman, ${ }^{2}$ we did not have to borrow money from others; he arranged all the costs. My husband also did not inform me about the costs. Before he went to Dubai, he tried to go to Saudi Arabia. He gave 70,000 rupees to a broker in Kathmandu, but the broker disappeared with our money and never showed up again. We have not recovered the loss yet. I think my husband wanted to go out at least once so that he could recover the money taken by the broker and payback to his father.

Before he went out, he used to help his father in the shop at Gauradaha. His father always told him that he should go out and make money. My father-in-law used to treat us badly, as if my husband would not do anything in life. My second brother-in-law had already gone abroad and started sending money and the last one had joined the police force, while my husband was helping his father in the shop. However, my father-in-law thought that my husband was helping because he was unable to find anything else.

4.2.1.3 Remittance: Use and Strategies My father-in-law collects the money from his sons and makes use of it, usually by investing it in residential plots for a profit. He does not inform me about the amount sent by my husband but I know that he has bought three residential plots at Gauradaha from the money sent by his sons. However, he [father-inlaw] does not discuss these things with his daughters-in-law. He also did not consult us about the purchase of these residential plots. I do not know which one is ours and which are for the brothers. I do not like this kind of the father-in-law, but I cannot do anything about it now. Perhaps after my husband's return, we have to discuss this issue with his father and get our share permanently.

4.2.1.4 Experience I do not think that my position in the family and the society has improved due to his migration. I am treated the same as before. However, many people nowadays ask me for loans. One thing I have experienced that money is everything for people. For example, before my husband went out, I was not treated well even by my inlaws, but now that he is out and making money, they cannot humiliate us anymore and say that we cannot do anything in life.

Even though I do not feel comfortable living alone after marriage, I think it is the male duty to make money, so I have accepted this challenge. He has gone out to make money for our future. I do not complain much. However, I always miss him. I always think of him. Money is not everything for me; it should be enough for two meals a day and clothing. He is making money abroad, which sometimes gives me a feeling of being more valued by the other family members, but it is very difficult to be separated.

I find it difficult to discipline the child in his absence. Although my parents-in-law love their grandson a lot, I think that is not always enough. Sometimes, he needs to be reprimanded to get him disciplined, but my parents-in-law love him so much that they have spoilt him. It is never like when my husband is present as a father for his son. I always feel this gap.

\footnotetext{
${ }^{2}$ Her father-in-law is a veterinary technician and operates an agro-vet shop at Gauradaha. He is also involved in the business of land brokerage for sometimes.
} 
4.2.1.5 Relation with In-Laws Apart from caring for my child I do not expect anything from my parents-in-law. I cannot share my feelings with my mother-in-law, but I can share things with my sister-in-law. Our in-laws do not allow us to do anything without their consent; you can imagine what kind of relationship we [also referring to her sister-in-law] have with them. I can quarrel with my husband but not with the in-laws. I cannot tell you that I have a bad relationship with them because I tolerate everything. If sisters-in-law are living together, it is obvious that there are some frictions between them, but in our case these are acceptable. Sometimes, it is about the division of work, sometimes about the children [her sister-in-law also has one son, of about 1 year]. So far, my relations with my sister-in-law are good, we are like best friends. I have a better relationship with her than with the parents-in-law. We share everything, like dividing the household tasks. Usually, one takes care of the children, while the other works in the kitchen. We discuss everything.

4.2.1.6 Communication and Bonding Nowadays, I have a regular contact with my husband through my mobile phone, usually once a week. I bought this mobile almost at the same time he went out. During talks, we spend a lot of time on household affairs and about his living there, not much on love; he is not that kind of person [laugh]. He even does not know how to talk about these matters, I can tell you. Even in this kind of situation where husband and wife live apart for a long time our relationship remains good. I think it is all due to our love and mutual trust." (Interviewed on 2009-12-21).

\subsubsection{Case 2: Sardevi Pasphiria: Not Overburdened}

4.2.2.1 Introduction Sardevi's (36) husband Surendra (40) has been living abroad for about 17 years. He worked in India for 15 years, now he is working in Malaysia. She was 16 years old when she got married. She is living with her two sons of 17 and 16 years old. Her house is in the courtyard of her parents-in-law. She is a de-facto head of her own household. In this ethnic group (Tajpuriya) people build a new housing unit within the parent's courtyard for their married sons. It is rare to marry off a son without providing a new housing unit within the courtyard. The houses do not have partitions and it would be inappropriate for the newly married couple to sleep within the same unit as the parents.

4.2.2.2 Migration: Decision and Involvement "He talked first with me when he wanted to go out and then with his parents. He had to go abroad for work because of the difficult situation at home. He tried hard to find a job here. He passed the examination of the Education Commission [to become a teacher] twice, but we did not have any connections and could not pay a bribe, so he failed to find a job. As the boys were growing, we did not have a good economic situation. We had to find something for a living. I had to accept his going out as we did not have other alternatives.

Going to India (Meruth) was not expensive, costing only 1,000 rupees. We did not borrow money from moneylenders but borrowed from my parents. For his move to Malaysia, we had a debt of about 100,000 rupees. The money was borrowed from a cooperative and I had to pay the interest every month on my own, as he could not send remittances immediately. I asked money from sashu [mother-in-law] but she refused.

4.2.2.3 Remittances: Use and Strategies By now, he has sent about 700-800 thousand rupees, but we do not have a surplus. We acquired a huge debt because of the treatment of our daughter, who was a heart patient. But all efforts were in vain: she sadly passed away at 
the age of two. We had to settle that debt as well. I have to buy almost everything for the household. The cost of education is high, but we consider this an investment in our sons. We have not bought any residential plots, but I have kept about 200 thousand rupees in a bank. As the sons are continuing their education, I cannot guarantee that we can make a surplus to buy a residential plot in town; they are saying that after grade 12 they want to go to Kathmandu for a bachelor's degree. They are really smart boys. They always rank first or second in their class and want to continue their education. I hope the remittances sent by my husband will be enough for that because he is making a good income now, unlike when he was in India. Whatever money my husband makes abroad, he sends it to me, and I have to invest a lot in the kids.

Sometimes we discuss that if we would be able to make surplus we will buy a residential plot at Gauradaha. My husband always tells me that after he makes money we would buy land elsewhere and move there. However, I have never thought of moving from this place. I would like to remain in this place that we got from our ancestors. I do not know why but I love it. However, if there is conflict of interest about where to live in the future, I will follow him.

4.2.2.4 Experience During his first move, I was still living with the parents-in-law, accompanied by sisters-in-law and other family members. I could share the tasks with them but I had sleepless nights. I was dreaming of him all the time. Gradually I got used to the situation and learnt to live without him. My life was horrible when he was in India. He did not have a good income and could not send (much) money. The economic situation was so poor that I could not even provide enough food to my children. I still remember that I skipped many meals. Imagine, at that time I was the most hated person in my in-laws' family! How could I survive! Gradually, especially after his move to Malaysia, the situation changed. Nowadays, I have also gained much hope, courage and confidence. I can go to them [in-laws] and ask what I need. I can quarrel with them if necessary, but at that time I was just hopeless.

In our community, women are always kept inside. They are supposed to work in the kitchen only, but not on the farm or outside. After his departure, I started going out. I learnt how to transplant rice and got to know the outside world. I got introduced to many people and started going to the market [where the money transfer agencies are located] to receive the money sent by my husband. In a way, I take these as positive changes. Though I have to manage the household on my own and work more than in the past, I do not feel overburdened. I am feeling good that I can go out, know many people, and can share my feelings with others.

So far, I am satisfied with my personal life, even if my husband stays separate. However, it is difficult to run a household as a single woman, especially if you are poor and surrounded by many problems. The society does not treat you well. Even if you go to market to buy something or to receive calls from the husband, people start talking about you: "Since her husband is not at home this lady is free, there is no one to control her, she goes wherever she likes". Leave alone the others, people within the family talk a lot, especially the sisters-in-law. Even when I go out of this courtyard, the family members talk about it. I have not heard much from outsiders though.

I do not have a problem to discipline my sons. My husband has been living out since they were very young and they do not know much about all these things. They do not wander around the village but focus on their studies. I am satisfied with them and have trust in them. They also obey me and are very understanding. As they are grown up, I have told 
them about the hardships that I went through raising them. I do not have dreams of doing something myself, but just to support them. Whatever money he [husband] is making, we have been investing in their study. We have high hopes of them.

4.2.2.5 Relation with In-Laws While I did not have a harmonious relation with my inlaws before, now they help me if I ask them, especially when I have to go out for group meetings or to the market. Whatever disputes we have and no matter how much we quarrel, now they help me, especially after he went to Malaysia and started making good money. Sometimes, we do quarrel with each other. You know, this is common in the relationship of a daughter-in-law with her in-laws in Nepal, which is even worse in our community. Quarrels mainly happen due to bad treatment of the daughters-in-law by their in-laws. For example, if they ask me something, I have to attend to that at any cost, no matter whether I am tired or busy. Sometimes, there are problems in dividing the work. They always want more from daughters-in-law, which is not always possible. If the nandas/amajus [husband's sisters] are there, there is even more conflict.

In the beginning, while I was still living with the in-laws and my husband, I was treated badly, especially by the female in-laws. He left me with them, I did not know what I should do, where could I get help from. One time, my son was asking for some food with his grandma, my jethani [husband's elder brother's wife] scolded him and chased him away. I was just looking at it; you can imagine how I felt. I was just crying all the time. I could not quarrel with them. What could I say to them; I did not know anything. At the time of marriage, I was just 16 years old. I was not mature and did not know what to do. Sometimes, when I was returning from the farm I would find my kids crying and nobody to take care of them. If my children fell sick, they [in-laws] never gave me money for treatment. They did not even care. Even if I fell sick, the same happened: they did not pay attention. However, I always got help from one of my dewars [brothers-in-law]. He always helped me to take my children to the health centre. He did not give me money but he was a great help. I had to manage the cost anyway. Sometimes I got money from my parents and sometimes my husband sent his earnings. Nowadays, my sons are grown up and I do not need anybody's help.

4.2.2.6 Communication and Bonding I have got a mobile phone since the last 6 months, given by my brother. My husband has bought one for me and he is trying to find someone coming to Nepal to bring it for me. He calls me twice or three times a month. Before I got this mobile, he used to call me only once a month. While he was working in India it was even worse, he used to call me only once in 2-3 months. We always talk about the future of our children, other household affairs, and about his experiences there." (Interviewed on 2009-8-16).

\subsubsection{Case 3: Parsila Sanam, Why Did I Marry?}

4.2.3.1 Introduction Parsila (24) got married with Dipu (35) in 2001. She is living with her parents-in-law; while her son (aged 7) is living at her maita [parental home of married women] studying at grade one. According to her, the private-boarding school is quite far from here $(2 \mathrm{~km})$ but close to her maita. She has up to $8^{\text {th }}$ grade of education. Dipu has been working in Dubai for many years. He started working abroad before they got married. This time he is out for already 6 months. 
4.2.3.2 Migration: Decision and Involvement "I do not know the exact year when he started working abroad because he was already a migrant at the time we got married. Actually, I do not consider him living here. We lived together for a year after marriage. After that, we have never lived together for more than 2 months. This time, he is in Dubai. It is his fourth move over there. I did not want him to go abroad after marriage. I did not like to stay behind for so long, but he convinced me that we would have a better future after migration, with the money he would be making abroad. I could not disagree, because if had he not gone abroad he would have ended up unemployed, just hanging around with his fellow chaps, not doing anything productive.

4.2.3.3 Remittances: Use and Strategies I do not know about the past, but since we married I receive the money he sends. When he sends money he instructs me what to do with it, like this much should be given to my father-in-law for household use, this much to deposit in the bank or lending money to someone, and this much for my personal use. I do not spend much of his income, I do not buy much for myself; I want to save for the future. I would rather buy golden jewellery but not expensive clothes. I used to give him all the details of my expenditures from his earnings, but now I have decided not to do that anymore because I found it complicated to make a very detailed overview. However, sometimes I feel like we have to be very careful in spending the money earned abroad. He would ask me whether I made unnecessary expenses because he is working hard to make money and we cannot just spend it profusely here.

So far, we have bought two residential plots, one at Damak and another one at Gauradaha. We have not added more agricultural land because that would require more labour, which we do not have. We cultivate this land on our own; we have not rented it out.

4.2.3.4 Experience I do not see any difference of being a migrant family, but people think that we have a lot of money. They frequently come to ask for money (loan), which I think was not the case before. Mostly, they come to me to ask for my personal money. Before, when I was still new to this family, people did not much interact with me but nowadays they come to ask me for a loan.

Although I am living with my in-laws, I always feel like I am alone. I do not feel comfortable being alone after marriage. For me, money is not everything. I know that my parents-in-law love me a lot, but it is never like living with a husband. Especially during the time when I get sick, I really miss him. Sometimes, I think why did I marry if I would have to stay alone? Wouldn't it have been better if I had remained single? At least I would not be thinking of my husband all the time. Anyway, I am not satisfied with being a migrant's wife, but I have to accept this challenge because sending my husband away is out of necessity rather than out of my free will.

I do not feel that I am free to move, because I am living with his parents. As he has kept me with his parents, I have to ask them whatever I do. So far, they are good in-laws. They let me do what I want, like joining the groups and going to maita. I do not complain about living with them as such. The only difficulty is that I always feel alone in his absence.

4.2.3.5 Relation with In-Laws I should say that my parents-in-law are supportive and they are kind to me. They allow me to go out and I don't have to worry about the house as they take care of my duties as well. I tell them that as I am alone (without husband); I need the company of my friends and want to go out with them. She [mother-in-law] does not object. 
4.2.3.6 Communication and Bonding My husband and I talk to each other over the mobile phone. We do not talk so frequently, sometimes once a week and sometimes twice a month. I have bought this mobile about one-and-a-half years ago. Before that, he used to call me over landline phone at home and even before when we did not have a connection at home, he used to call me at maita where my parents had a landline phone. We had a kind of schedule to go to maita to receive his call. There was a public booth at Gauradaha and he also used to call me there but I always felt uncomfortable talking about personal matters in a public booth. I preferred to go to maita.

We always talk about love during the phone calls. What else, if you get an opportunity to talk to your husband, who would think of talking about other issues? Our talks over the phone are related to love, apart from small talk about our child. As I am not involved in household affairs, we do not talk about these things unless it is related to the use of his earnings.

Even in this kind of situation where husband and wife live apart for a long time our relationship remains as usual. I think it is because of the mutual trust between us. Whatever he does abroad, I trust him. I hope he would not do bad things there, like going to another woman. I hope he is like me, who is always thinking of him and missing him all the time. I cannot go beyond the social norms because of the trust with him and I expect the same from that end." (Interviewed on 2009-12-20).

\subsubsection{Case 4: Ushadevi Presta, Migration Means a Lot}

4.2.4.1 Introduction Ushadevi (34) was married to Chitra (43) at the age of 19. During the time of marriage her husband was 28 years old. Her husband is working in Qatar for the last 4 years. She is illiterate. The couple has two children: a daughter Trisna (aged 14, studying at tenth grade) and a son Suzan (aged 12, studying at seventh grade), both studying at a private boarding school at School Chaun.

4.2.4.2 Migration: Decision and Involvement "My husband is working in Qatar for the last 4 years. During this period, he visited us once. Before he went abroad, he used to work in the factory as a labourer, as we do not have sufficient land for farming. He was paid very little, which forced him to decide to go abroad. He discussed this with me. When he told me, I did not feel bad because we were in debt so badly that there were no ways to redeem. I thought once he goes out we would have more income, could pay back the debts, and could send our children to better schools. So, I actually liked his idea of going out for work.

We did not have money to invest for his migration. We borrowed money from the moneylenders at the rate of three rupees (monthly interest of 3\%). Together we looked for the money needed. Though he has gone abroad and sends money back, his income is not so high and it took a long time to pay back all the money we borrowed. In total, we spent 120 thousand rupees for the whole process.

4.2.4.3 Remittances: Use and Strategies He earns only about 8,000 rupees per month. He always complains about the situation over there and that he is not making good money. Every time he calls me he complains about his income. As he has to spend it on food, making phone calls here, personal use, he cannot save much money to send to us. He has not sent money since he sent 10,000 rupees during the last Dashain [the biggest festival of Nepal]. Till now, he has earned just enough to pay the debts. We have no surplus. I got terribly sick last year. I spent a huge amount of money. We had a very small hut which we 
replaced with this house. [The house is not that big but enough for four people. It is not a concrete house; it has CGI roofing and mud and bamboo walls.]

Usually, he instructs me on the use of the money he sends but sometimes I spend it on my own. He has to instruct me. Especially if he has promised money to someone whom he has borrowed from, he instructs me to pay this much to this person. However, if it meant to be to be spent on household use I decide by myself.

4.2.4.4 Experience I cannot say much about my social position, but my husband's working abroad means a lot for us. We became able to send our children to the private school [they were in government school before their father's move]; we do not have to borrow food from others though we have not added assets like a television, land, etc. As we do not have much land we would otherwise have to borrow the money from moneylenders to buy food. I have installed a tube-well on our land and produce rice twice a year. Before his migration, I can tell you, people would not trust on us even for 100 rupees, but now if I ask money they easily lend to me as they see that my husband is making money abroad and I would pay them back easily.

However, running a household alone feels like a huge burden. The additional tasks are such as finding male labours especially during ploughing time, finding other labours for transplanting, and so on. Being involved in these activities takes a lot of time. I do not complain about my situation, as I am managing well on this end. Apart from the additional tasks, I have no complaints about my living alone because this is something I am taking as a challenge and he is doing something for the family. So, why would I fuss?

I do not have any problems in disciplining the children; though I faced a lot of problems when they were young. I did not get any help from my in-laws and he has never been at home. It is very hard for me to explain, but I remember going through a lot of hardship. Now I have no problems regarding my kids. They even help me in the calculations of interest on the money we borrowed.

I have to say that I am satisfied because I have no choice but accepting this situation. The tragedies and hardships are in my heart, why should I expose them? We are obliged to live in this situation because of our poverty. It is a necessity for them [husbands] to go out for work and it is our fate [of wives] to handle the household.

4.2.4.5 Relation with In-Laws Sometimes, I get help from my in-laws in any kind of difficult tasks. Especially, when I get sick they come here to do the household chores. So far, I have a good relationship with them. They have been helping me in times of need. I do not expect much from them; as I am separated, I am supposed to run my family on my own.

4.2.4.6 Communication and Bonding We talk over the mobile phone, which he sent to me last year. Before that I had to go to School Chaun (public telephone booth) or sometimes to the in-laws' house where they have a landline connection. At that time, the frequency was once in 2 weeks or once a month, but now he calls me almost every day, at least twice a week. We mostly talk about household matters and his living over there. We talk less about our personal feelings. Before, as I had to go out or at public place we did not talk about love, but this mobile is really handy to talk with him about personal things." (Interviewed on 2009-12-23). 


\subsection{Analysing the Cases}

Common to all the women's stories is that they seem to be satisfied with the improved economic situation since the migration of their husbands, but they have mixed experiences in terms of subjective wellbeing. Some have problems with disciplining children in the absence of fathers (Case 1), while others miss their husband all the time (all cases). Dwiyanto and Keban (1997) also report difficulties in disciplining children in a situation of male out-migration (cited in Nguyen et al. 2006). However, all women wanted their husbands to work abroad to improve the economic situation. The remittances sent by their husbands inspired them to endure the present in order to earn a secure future for themselves and their children. For them, it is a challenge to stay behind, but they are accepting it 'for the future'. Our data are similar to those of a survey carried out in Uttarakhand, India, which showed that the majority of women was happy about the migration of their husbands as the women believed it was necessary to ensure a better future for their children (cf. Hoermann et al. 2010).

One of the important changes brought about by male out-migration is an increased labour participation of women in agriculture. Especially de-facto female heads of households show a higher degree of participation in agriculture as compared to the women living with their in-laws (Gartaula et al. 2010). Studies have also proven that the women left behind due to male out-migration are facing greater responsibilities and an increased workload (Gardner 1995; Hadi 1999; Kaspar 2006). This does not only include their physical participation, but also their mental feeling of being overburdened by the additional work. A review of studies in Nepal and India also concluded that "the increased workload has a detrimental impact upon women's health, leading to a rise in mental tension and physical stress, particularly for women heading nuclear families, as they cannot depend on other male relatives in the absence of their husbands" (Hoermann et al. 2010: 22).

In the case of women living with their in-laws, many of the additional tasks are shared by other household members, while the women who are de-facto heads of households have to perform them all themselves. Case 1 shares her tasks with a sister-in-law, while the parents-in-law help the woman in Case 3. Case 4 clearly illustrates that running a household by a single person is a burden because of the additional tasks to be performed in the husband's absence. Interestingly, the woman in Case 2 does not feel overburdened, though being a de-facto head of the household she has to engage more in agriculture, household and community affairs than before. She rather considers these as positive changes in her life that have increased her self-confidence and agency. Hoermann et al. (2010) also observed an increased self-confidence of women due to male out-migration.

On the one hand, the women seem to agree on the idea that 'money matters' when talking about migration, remittances, its use and their imagination of a future living a better life. On the other hand, when we talked about staying separate they easily agree that money is not everything in life. During the interviews, we noticed their body language when speaking about their subjective experience of living apart from their husband: they would turn their face downward and blush, and we could observe that they were not satisfied at all with their situation. These facts in fact cannot be 'measured' by objective indicators of wellbeing as stated in the literature (Doyal and Gough 1991).

The case studies further confirm that money contributes to people's wellbeing to the extent that it satisfies the material needs, but that subjective wellbeing is subject to prior economic situation and relative to overall living environment of an individual (see Diener and Biswas-Diener 2002). The income from remittances means a lot to the women in Cases 
2 and 4 to improve their basic living conditions and they seem to be more satisfied than the women in the other two cases, although Case 4 reported low earnings of her husband. Whereas for the women in Case 1 and 3 the income from remittances is used to buy residential land, jewellery and other assets, which is for future wealth rather than improving their everyday present life. The essence of marriage is addressed in Case 3 where the woman faces the challenge of the union of a man and a woman as living-together that is broken by long-term migration, which affects their sexual life especially in a culture where extramarital relations are not permitted. Analysing the fulfilment of their sexual desires, however, is beyond the scope of this paper, the situation shows their state of wellbeing where they have to stay alone for most of their sexually active age. In such a situation, a long time separation from husbands can result into a feeling of marital insecurity among the women left-behind. This was observed by Hoermann et al. (2010), where respondents in India were afraid of their migrant husbands developing extra-marital relations in the cities.

The women seem to believe that their relationship with husbands has not weakened due to the mutual trust between husband and wife. They have a regular contact with their husband through mobile phones. Before the introduction of the mobile phone, the communication between wives and migrant husbands was less frequent. Except for the handwritten letters, the landline phones in the village and market centres were the only means of communication. Due to the introduction of mobile phones, the women's communication with their husbands has not only become more regular, but also more personal. This enables the wife to experience a transnational living through a continuous interaction with her husband. In all the cases presented above the women talk about household affairs and the children's education. Only in Case 3 the woman reported talking more about love. In all cases, husbands instruct their wives about the disbursement of remittances and household affairs. In this sense, husbands are performing a double engagement (Grillo and Mazzucato 2008) by being involved in both the household at home and at their destination.

The above descriptions clearly show the patriarchal control over household resources, either by the husbands or the father-in-law, depending on the woman's living arrangement. The women who are living as de-facto head of the household can exercise more autonomy in resource mobilisation and their own mobility than the women living with in-laws, who are still under the control of the parents-in-law. The women in Case 2 and 4 were well involved in decision-making during their husbands' migration and they also have some autonomy to use and allocate the remittances, though they are still controlled from abroad. The wife in Case 1 did not have any voice in decision-making and does not know what the remittances are used for. Hoermann et al. (2010) likewise report that in joint-family households the remittances are usually received by the in-laws and spent according to their own priorities, while some wives receive a small amount of money from their husbands without the knowledge of their in-laws. The wife in Case 3, however, seems to have more control-though instructed by the husband-over the use of remittances than her parentsin-law. This may indicate an important power shift in the use of the sons' earnings from parents to wives.

The examples also reveal that the relationship of these daughters-in-law with their parents-in-law varies from very cold (Case 1) to more harmonious (Case 3). They still get support from their parents-in-law in performing the household tasks. Those living with their in-laws receive direct material and physical support, while those living as de-facto household heads receive more indirect support and counselling, especially in agricultural activities. For example, in Case 1 the woman gets help from her mother- and sister-in-law in household work and taking care of her son. It seems common for two sisters-in-law to 
share their tasks as well as their feelings, about which the parents-in-law are not very sympathetic. However, even a good relationship with the in-laws cannot compensate for the absence of the husband (Case 3).

The situation of women living as de-facto household heads is different as they live separately and run their household independently. The wife in Case 2, however, gets support from her in-laws to enable her to go to the group meetings and to the market. Her relationship with her in-laws improved since her husband moved to Malaysia. Although with age and after childbearing women's autonomy and self-esteem generally increase (Agarwal 1997; Kabeer 1996), the autonomy of the wife in Case 2 can be attributed to her increased income from remittances and reduced dependency. Her enhanced self-esteem has to do with her involvement in groups and cooperatives. Indeed, joining groups and cooperatives helps women increase their self-esteem and self-confidence. However, this is visible mainly where women are among themselves, like in a women's group, but not necessarily in the home situation (Gartaula et al. 2010). The latter applies especially to women living with in-laws. It could be concluded that women living as de-facto heads of households have a better subjective wellbeing than women living with in-laws, despitebut maybe also because of - the former's increased responsibilities and workload to run a household and function in the public sphere.

\section{Conclusion}

The paper has examined objective and subjective wellbeing of migrants' wives using the framework of the migration-left-behind nexus in a transnational social field. The material or objective dimension of their wellbeing has evidently improved due to increased income from remittances sent by their husbands. In general, the economic status, access to food and water, child education, housing, and access to health services have been improved due to the out-migration of their husbands. However, the cognitive and emotional dimensions of relations with immediate kin (in-laws) are more contexts specific, and have often not improved. In this respect, remittances do not increase the subjective wellbeing of migrants' wives, particularly those who are living with their in-laws.

The four cases imply two comparisons: the first one is between women of poor and more well-to-do households and the second between women acting as de-facto household heads and women living with in-laws. Regarding the first, it seems that migration for women in poor households relieve them from economic hardship, which makes them more satisfied than women in relatively well-to-do households. The latter did not have to endure much economic hardship before and their situation does not change much with the increased income from remittances for a basic living. They rather like their husbands to stay with them. The second comparison shows that women as de-facto heads of the households can exercise more power and autonomy when their husbands are absent, which appears to be satisfying. Migrant wives who are living with in-laws are sometimes even under stricter control in the absence of the husband, which seems to make them less satisfied with the situation. They always have to ask for permission from their parents-inlaw, which is not easy if the in-laws are not supportive. Finally, women as de-facto heads of the household have more responsibility in household management and face an additional workload in the absence of their husbands, while women living with in-laws can share their work with other household members and the households are managed by their parents-inlaw. However, it would be naïve to assume that increased responsibilities would have a negative impact on wellbeing. The woman in Case 3 clearly shows that she considers these 
things as positive changes in her life. It can be concluded that the subjective and relational dimensions of wellbeing are complex and multi-faceted.

In the literature, the transnationality of migrants has been well described. Grillo and Mazzucato (2008) observe that although it is important to assess the value of transnationalism by doing research that is physically located in both the places of origin and destination, it is not a necessary condition: "Transnationalism may be observed from one site or many within a single social field" (Grillo and Mazzucato 2008: 191). This paper supports their argument, but it does more. By focussing on the women left behind we have shown that they also experience a double engagement. Like their migrant husbands they also experience living transnationally, not by changing places but by using modern means of communication such as mobile phones. During telephone talks, they spend time on household management as much as on the situation of their husbands abroad, and they make plans together that are important for the future of their children and their own wellbeing. The husbands abroad experience this double engagement by directing household affairs and keeping distant control over the use of remittances.

Finally, this paper challenges economic theories that view migration as a free choice intended to maximize utility from scarce resources (cf. Shrestha 1988) and theories that emphasise migration as an individual rational decision of the migrants themselves based on wage differences, labour equilibrium and income maximisation between the places of origin and of destination (Massey et al. 1993; Spaan 1999). We have been able to illustrate that in practice decision making about migration is a collective household decision or a decision between husband and wife, even if the wife has little power to direct the final outcome. Migration is not a one-time spatial movement, like Xiang (2007) asserts for China with the notion that those physically left-behind are also left-behind socially and economically. Instead, it should be regarded as a continuous spatial and temporal process. Furthermore, the women left behind are not passive observers but are actively engaged as strategic participants in that process. The paper shows that the women left behind are strongly engaged in migration decisions, not only to let migrants leave but also to redeem the debts incurred in the process and in the utilisation of remittances. Hence, migration is more a family or household decision than an individual choice of the migrants themselves (de Haas 2005; Massey et al. 1993; Yeoh et al. 2005). However, it would not be correct to consider the women left behind as one undifferentiated social category because their involvement, autonomy, and influence depend very much on household arrangements. The women who can act as de-facto heads of a household have more power in decision-making than the women living with their in-laws.

Acknowledgments The authors acknowledge the generous support of the Neys-van Hoogstraten Foundation, the Netherlands, for the fieldwork of the first author in Nepal during 2008-2009.

Open Access This article is distributed under the terms of the Creative Commons Attribution Noncommercial License which permits any noncommercial use, distribution, and reproduction in any medium, provided the original author(s) and source are credited.

\section{References}

Agarwal, B. (1997). "Bargaining" and gender relations: Within and beyond the household. Feminist Economics, 3(1), 1-51.

Brons, J., Dietz, T., Niehof, A., \& Witsenburg, K. (2007). Dimensions of vulnerability of livelihoods in lessfavoured areas: Interplay between the individual and the collective. In R. Ruben, J. Pender, \& 
A. Kuyvenhoven (Eds.), Sustainable poverty reduction in less-favored areas (pp. 91-110). Oxfordshire and Cambridge: CAB International.

Camfield, L., Choudhury, K., \& Devine, J. (2007). Well-being, happiness and why relationships matter: Evidence from Bangladesh. Journal of Happiness Studies, 10(1), 71-91.

CBS. (2001). National population census 2001. Kathmandu: Central Bureau of Statistics, National Planning Commission, Government of Nepal.

CBS. (2004). Nepal living standard survey 2003/04: Statistical report volume two (data). Kathmandu: Central Bureau of Statistics, National Planning Commission, Government of Nepal.

DDC. (2006). District profile of Jhapa. Bhadrapur, Nepal: District Development Committee, Jhapa and Bureau of Statistics, District Office, Morang.

de Haan, L., \& Zoomers, A. (2005). Exploring the frontier of livelihoods research. Development and Change, 36(1), 27-47.

de Haas, H. (2005). International migration, remittances and development: Myths and facts. Third World Quarterly, 26(8), 1269-1284.

Diener, E., \& Biswas-Diener, R. (2002). Will money increase subjective well-being? Social Indicators Research, 57(2), 119-169.

Doyal, L., \& Gough, I. (1991). A theory of human need. Hampshire and London: Macmillan.

Elmhirst, R. (2008). Multi-local livelihoods, natural resource management and gender in upland Indonesia. In B. P. Resurreccion \& R. Elmhirst (Eds.), Gender and natural resource management: Livelihoods, mobility and interventions (pp. 67-87). London: Earthscan.

Gardner, K. (1995). Global migrants, local lives: Travel and transformation in rural Bangladesh. Oxford: Clarendon.

Gartaula, H. N. (2009). International migration and local development in Nepal. Contribution to Nepalese Studies, 36(1), 37-65.

Gartaula, H. N., Niehof, A., \& Visser, L. (2010). Feminisation of agriculture as an effect of male outmigration: Unexpected outcomes from Jhapa district, eastern Nepal. The International Journal of Interdisciplinary Social Sciences, 5(2), 565-578.

Grillo, R., \& Mazzucato, V. (2008). Africa <> Europe: A double engagement. Journal of Ethnic and Migration Studies, 34(2), 175-198.

Hadi, A. (1999). Overseas migration and the well-being of those left behind in rural communities of Bangladesh. Asia-Pacific Population Journal, 14(1), 43-58.

Hoermann, B., Banerjee, S., \& Kollmair, M. (2010). Labour migration for development in the western Hindu Kush-Himalayas: Understanding a livelihood strategy in the context of socioeconomic and environmental change. Kathmandu: International Centre for Integrated Mountain Development (ICIMOD).

Jones, H., \& Kittisuksathit, S. (2003). International labour migration and quality of life: Findings from rural Thailand. International Journal of Population Geography, 9(6), 517-530.

Kabeer, N. (1996). Agency, well-being and inequality: Reflections on the gender dimensions of poverty. IDS Bulletin, 27(1), 11-21.

Kaspar, H. (2006). "I am the head of the household now": The impacts of outmigration for labour on gender hierarchies in Nepal. In S. Premchander \& C. Muller (Eds.), Gender and sustainable development: Case studies from NCCR North-South (pp. 285-303). Bern: NCCR North-South, Swiss National Centre for Competence in Research.

Kaur, R. (2006). Migration for work: Rewriting gender relations. In S. Arya \& A. Roy (Eds.), Women and migration in Asia: Poverty, gender and migration (Vol. 2, pp. 192-213). New Delhi, Thousand Oaks, London: SAGE Publications.

Kollmair, M., Manandhar, S., Subedi, B., \& Thieme, S. (2006). New figures for old stories: Migration and remittances in Nepal. Migration Letters, 3(2), 151-160.

Krishna, S. (2004). A "genderscape" of community rights in natural resource management. In S. Krishna (Ed.), Livelihood and gender: equity in community resource management (pp. 17-63). New Delhi: Sage Publications.

Kuhn, R. (2006). The effects of fathers' and siblings' migration on children's pace of schooling in rural Bangladesh. Asian Population Studies, 2(1), 69-92.

Lokshin, M., Bontch-Osmolovski, M., \& Glinskaya, E. (2007). Work-related migration and poverty reduction in Nepal (World Bank Policy research working paper 4231). Washington DC: The World Bank.

Massey, D. S., Arango, J., Hugo, G., Kouaouci, A., Pellegrino, A., \& Taylor, J. E. (1993). Theories of international migration: A review and appraisal. Population and Development Review, 19(3), 431-466.

Mazzucato, V. (2008). The double engagement: Transnationalism and integration. Ghanaian migrants' lives between Ghana and the Netherlands. Journal of Ethnic and Migration Studies, 34(2), 199-216. 
McGregor, J. A. (2004). Researching well-being: Communicating between the needs of policy makers and the needs of people. Global Social Policy, 4(3), 337-358.

Newton, J. (2007). Structures, regimes and wellbeing (WeD working paper 30). Bath: ESRC Research Group on Wellbeing in Developing Countries, University of Bath.

Nguyen, L., Yeoh, B. S. A., \& Toyota, M. (2006). Migration and the well-being of the 'left behind' in Asia. Asian Population Studies, 2(1), 37-44.

Niehof, A. Conceptualising the household as an object of study. International Journal of Consumer Studies (forthcoming).

Ontita, E. G. (2007). Creativity in everyday practice: resources and livelihoods in Nyamira, Kenya. PhD Thesis, Wageningen University, Wageningen.

Portes, A., Guarnizo, L. E., \& Landolt, P. (1999). The study of transnationalism: Pitfalls and promise of an emergent research field. Ethnic and Racial Studies, 22(2), 217-237.

Ramirez, C., Dominguez, M. G., \& Morais, J. M. (2005). Crossing borders: Remittances, gender and development. Santo Domingo, Republica Dominicana: United Nations International Research and Training Institute for the Advancement of Women, INSTRAW.

Rigg, J. (2007). Moving lives: Migration and livelihoods in the Lao PDR. Population, Space and Place, 13(3), 163-178.

Royo, M. G., \& Velazco, J. (2006). Exploring the relationship between happiness, objective and subjective well-being: evidence from rural Thailand (WeD working paper 16). Bath: ESRC Research Group on Wellbeing in Developing Countries, University of Bath.

Rudie, I. (1995). The significance of 'eating': Cooperation, support and reputation in Kelantan Malay households. In W. J. Karim (Ed.), 'Male' and 'female' in developing Southeast Asia (pp. 227-245). Oxford/Washington DC: Berg Publishers.

Schyns, P. (2002). Wealth of nations, individual income and life satisfaction in 42 countries: A multilevel approach. Social Indicators Research, 60(1), 5-40.

Seddon, D., Adhikari, J., \& Gurung, G. (2002). Foreign labour migration and the remittance economy of Nepal. Critical Asian Studies, 34(1), 19-40.

Sen, A. (1990). Gender and cooperative conflicts. In I. Tinker (Ed.), Persistent inequalities: Women and world development. Oxford and New York: Oxford University Press.

Sharma, J. R. (2008). Practices of male labor migration from the hills of Nepal to India in development discourses: Which pathology? Gender, Technology and Development, 12(3), 303-323.

Shrestha, N. R. (1988). A structural perspective on labour migration in underdeveloped countries. Progress in Human Geography, 12(2), 179-207.

Spaan, E. (1999). Labour circulation and socioeconomic transformation: The case of East Java, Indonesia. PhD Thesis, Rijksuniversiteit Groningen, Groningen.

Taylor, E. J. (1999). The new economics of labour migration and the role of remittances in the migration process. International Migration, 37(1), 63-88.

Taylor, J. E., Arango, J., Hugo, G., Kouaouci, A., Massey, D. S., \& Pellegrino, A. (1996). International migration and community development. Population Index, 62(3), 397-418.

Thieme, S., \& Wyss, S. (2005). Migration patterns and remittance transfer in Nepal: A case study of Sainik Basti in western Nepal. International Migration, 43(5), 59-98.

Toyota, M., Yeoh, B. S. A., \& Nguyen, L. (2007). Bringing 'the left behind' back into view in Asia: A framework for understanding the 'migration-left behind nexus'. Population, Space and Place, 13(3), $157-161$.

Velayutham, S., \& Wise, A. (2005). Moral economies of a translocal village: Obligation and shame among South Indian transnational migrants. Global Networks, 5(1), 27-47.

White, S., \& Ellison, M. (2006). Wellbeing, livelihoods and resources in social practice (WeD working paper 23). Bath: ESRC Research Group on Wellbeing in Developing Countries, University of Bath.

Xiang, B. (2007). How far are the left-behind left behind? A preliminary study in rural China. Population, Space and Place, 13(3), 179-191.

Yeoh, B. S. A., Huang, S., \& Lam, T. (2005). Transnationalizing the 'Asian' family: imaginaries, intimacies and strategic intents. Global Networks, 5(4), 307-315. 